\title{
Communication Potential of Information Technologies in Global Educational Space
}

\author{
Svetlana V. Burmaga* \\ Siberian Federal University \\ 79 Svobodny, Krasnoyarsk, 660041, Russia
}

Received 08.12.2014, received in revised form 20.01.2015, accepted 28.03.2015

The article analyzes new communication opportunities, arising in the system of education with the use of modern information technologies. Basing on socio-philosophical analysis, the author proves that obvious advantages are accompanied by the problems, many of which are of alienation character. These are, in particular, violation of traditional subject-object relations at the university as well as formation of new distant relations among the youth.

Specific features of interaction of information and education largely determine potential directions of all social institutions' development. With this regard socio-philosophical analysis is of a particular relevance, since the philosophy of information in Russia is intensively developing and plays an increasingly important role in science due to the on-going process of the global information society formation. One of the consequences of the accelerated reform of the educational sphere, aiming at the introduction of information technologies, is alienation among the youth and students in particular.

Modern society is characterized by strengthening of many links in it. As for the educational system, the information society turns it into a manufacturer of the production means, a human intelligence generator. This results in the fact that the elements inherent to the economic institute appear in it. Currently it is possible to say that a human exists in different educational spaces simultaneously, some of which are interrelated and inter-supplemental, but others are either poorly linked or autonomous to a great extent.

The process of informatization and computerization of society favours the formation of information educational subspace. The computer with its rich operating system contributes to the dialogue of different cultures.

A human's formation in the educational process can be shaped by the process of information movement and accumulation. In this case it is considered to be a sort of evolutionary information process. Consequently, informatization must become an important element of state policy in the field of education, especially for Russia, since modernization of Russia, being a manifestation of a new great innovation cycle, is impossible without informatization of culture and processes and structures linked to it.

Adaptation in contemporary social and information environment is determined by the necessity of a subject of education's spiritual development. This presupposes not only a human's knowledge, competence, and intelligence, but also the culture of his / her activities, relations, ethics, modern worldview, his / her following social and legal as well as moral norms, being careful to moral values. One of the main causes of inactive transition to the information education, based on innovations, use of new information technologies, latest achievements of economy, science, and pedagogical thought, is pedagogical conservatism with its old traditional methods of teaching. Differentiation in modern

(c) Siberian Federal University. All rights reserved

* Corresponding author E-mail address: svb.704@yandex.ru 
education presupposes integration of many academic subjects through interdisciplinary links. Global educational environment contributes to integration of humanitarian and natural-science subjects. This involves finding sources of interdisciplinary links and means of their implementation via offering unique techniques. This process aims at the formation of system of scientific thinking, ecological and information culture, creative activity and high morals, the qualities leading to successful adaptation, life and work in global information society.

Keywords: communication potential, information technologies, educational space, alienation, global information society, information resource.

Research area: philosophy.

All specific features of modern civilization development caused by global informatization of society are radically new. They emerged within the past two to three decades and have no analogues in the historical past of the mankind. Therefore, these issues are insufficiently studied so far. Some of them have not even found their adequate reflection in mass consciousness yet, which is now significantly behind the pace of a global process of society informatization. Such lagging behind is another global threat to safe and sustainable development of civilization. That is why it is vital to study the processes of informatization of modern society comprehensively, taking into account their interdependence with the other two strategic issues - that of society's globalization and its sustainable and safe development.

Specific features of interaction of information and sphere of education largely determine potential directions of all social institutions' development. With this regard the sociophilosophical analysis gets its particular relevance since the philosophy of information in Russia is intensively developing and plays an increasingly important role in science due to the process of the global information society formation. This problem is not only interdisciplinary and general scientific but global and even cosmic. This is proved by modern approaches to the analysis of cosmology issues and the issues of other space sciences (A.D. Ursul, T.A. Ursul, 2012). One of the consequences of the accelerated reform of the educational sphere, aimed at introduction of information technologies, is alienation among the youth and students, in particular.

Nowadays the content, goals and objectives of global education are increasingly lagging behind the global trends of the information society development. It is primarily evident in the fact that as a result of commercializing educational services received their specific monetary value. This consequently led to a pragmatic approach to education which finds its manifestation in "obsession", "everydayness" in solving practical problems, in particular, while a human, living in the modern world, is destined to solve complex, diverse tasks that require not only professional training but also fundamental and liberal education of high-quality (Gabinsky, 2007).

In this respect, praxeological and axiological issues of information flows ambivalence in universities become urgent (Ponomareva, 2008). In a situation of inconsistency of contemporary education and heterogeneity of global educational spaces any person in any society and region must have a potential opportunity to choose an educational system appropriate to his values, personal and national cultural priorities. Therefore, it is worth while focusing on one of the issues that make it possible to consider education as a significant reserve of national development. It is the issue of identification as the most important one from the point of view of an individual's awareness of his / her national identity and cultural specificity. 
Dwelling upon an ontological aspect of education, Hegel noted that an individual human being's ascent to his / her universal nature is educating him/herself(Hegel, 1998). Education of a human and, consequently, of the whole society is the process of his / her formation. This thesis is developed in modern terms by N. Rybakov: "Education is a never-ending process of mapping and meeting of a man and the world, resulting in new forms of their mutual existence" (Rybakov, 2003). In other words, information plays a fundamental role in full functioning of education, as education is viewed as a process of interaction between a man and the world and is not limited to learning at educational institutions.

An amazing process of accelerated globalization and informatization of society is typical for the present-say situation. The world has entered a new information epoch, which, according to some forecasts, will last for centuries. Humanity has been coping with completely new resource - information. If earlier, in the industrial era, a human's main problems were how to use the energy of steam, electricity and atomic nucleus, now he / she faces the era of information. It was in the late 80-ies of the XX century when Prof. A.I. Rakitov stated a strategic social significance of the process of the society's informatization which he termed a socio-technological revolution (Rakitov, 1991).

Qualitative transformation of many social groups marks a transition from one type of functioning to a different one. Their sequence is embodied in the process of organizational epochs alternation, each shaping the dynamics of its system of division of labor, i.e. new qualitative forms of social relations and interactions that were absent in previous epochs (Kushelev, 2007).

Information resources are assigned a special role in global education. These are a collection of data organized to obtain reliable information, data being the information processed and presented in a formalized way for its further processing. The use of these resources has improved the validity and efficiency of the decisions made at enterprises, industries, banks and other activities due to the timely use of necessary information.

Based on the appropriate level of information society, modern education is associated with the fact that civilizational unity of individual countries and peoples constantly stumbles over their cultural differences and peculiarities of historical development (Chumakov, 2011). In this context problem of the educational system stability is vital though this issue is being debated by the scientists. However, the apparent incompatibility between sustainability and development, which caused a strong emotional protest of academician N.N. Moiseev, a "patriarch" of this problem, has not disappeared. He pointed out that sustainability means invariability whereas development, in principle, implies changes, something new. $\mathrm{He}$ argued that a country's sustainable development is connected with other countries' development, "with the planetary background". According to him, Confucian civilization, for example, becomes more capable of survival and human values must be substituted by the quality of the work performed, particularly in the area of new technologies (Ardov, 2012). Although construction, testing, and optimization of such technologies are issues of the future, the work at their creation begins today. However, it is important to understand the danger of the idea that to be progressive means to inscribe oneself to a historical process which is understood in a purely Eurocentric sense (Iatsenko, 2009).

Peculiar features of information policy in the sphere of education are determined by the need for effective response to non-constructive reform efforts, which can cause the processes of alienation among the youth. This is due, in particular, to specific features of the educational system reform since such reforms 
are often aimed at imposition of alien norms and standards. In this regard the educational system reveals specific innovative information resulting from socio-economic, geographic, cultural and other features of the educational system of a particular country. To study various types of innovations there appeared a new field of socio-humanitarian knowledge - Innovatics (Prigozhin, 1989).

Innovation process in education is a dynamic polystructural system (Kotliarova 2003) with several major elements, and namely activity, subject, and level elements. The level of innovations (federal, regional, municipal) is of crucial significance. It implies the maximum participation of the administration, teachers, students, and parents as subjects of the innovation process. Innovation processes have always accompanied human history. However, in the course of time the dynamism of innovation processes got accelerated, and in the XX century it became clear that humanity's wealth was achieved revolutionarily (Toffler A., Toffler Kh., 2007).

In today's world we might speak of a new transitional phase, a new scientific revolution, the fourth global revolution, according to V.S. Stepin (Stepin, 2006). Whereas philosophy had no need in the humanities as a methodological basis for overcoming the crisis, the humanitarian sphere of thought and language relation is a key to the fourth global scientific revolution. This important point is manifested in information processes, on the one hand, as well as in education, on the other hand. It is so because the expected educational revolution or even a number of such revolutions in the XXI century will be not only in informatization, futurization, globalization, humanization of education (and in a number of other trends in their systemic interconnection) but in certain informative evolution of the subject of educational activity (Kolin, 2010a).
In a quantitative aspect the education integrity involves the learner's broad scientific and humanistic worldview formation. As for a qualitative aspect, it implies a high level of formation of several things including not only the students' holistic professional knowledge but also the qualities of citizens and men of high morals (Kulipanova et al., 2012).

Educational materials provide the information about what is already scientifically proved; hypotheses and assumptions are usually not considered. Such an approach is no longer effective in the global world. It is due to the increasing flow of information, primarily in the field of fundamental scientific discoveries. At the same time the process of scientific and educational information ageing has significantly accelerated. In this respect one can agree with A.M. Ivanitskii, who argued that "the basis of consciousness is the idea of renewal, assigning an ultimate meaning to life and causing a human's constant desire for novelty" (Ivanitskii, 2004).

According to the ontological approach, education must be focused on an individual's formation, which is only partially taken into account in the conception of education aimed to "impart scientific knowledge and form a set of skills and abilities of headwork, being the minimum required for the inclusion in social production". In its most primitive understanding the educational system provides information. This is a traditional understanding of the information and education relation before the era of global transformations. It implies that up to the end of the XX century the teacher was the only source of information and criterion of its truth. However, in traditional education the teacher was primarily associated with the source of new information. This image is still imprinted in minds of people of traditional societies, for example, in the East. However, in the information revolution era this role has changed, resulting in a change 
of the traditional subject-object relations in an educational institution. It is due to the drastic decrease of the teacher's role as the source of new information at the end of the XX century. In most cases students get information quicklier on the Internet, i.e. outside the educational system, and have no need in the teacher as a source of new information. However, after the first Internet euphoria was over the students felt the need in teachers again as they were trapped in the information flows. The teacher has to 1) be a criterion of the information validity and 2) systematize new knowledge.

When teaching gets its adequate civilizational orientation without losing its ethno-cultural connotation, the educational system itself changes fundamentally. This fact is of a crucial importance in the analysis of the role of information in the educational process. When regional and ethnic features are taken into account in educational conceptions it makes it possible to consistently shape the identity, which is hardly possible without a certain level of providing information. A.G. Dugin fairly states that it is vitally necessary to form the educational system, as we lost it. Thus, it needs to be preserved, strengthened and passed on to succeeding generations (Dugin? 2012). In this case information gains its local character in education.

Humanism and humanization can also lead to the heights of spiritual enlightenment as well as to the abyss of selfishness, inherent worth of individual existence. The ways of humanistic progress turned out to be different but the spiritual disaster, to which these paths led, was quite similar (Korol'kov, 2006). This is because the main goal is as much as the change in mentality, mental or paradigmatic foundations of the whole non-Western world's life (about $4 / 5$ of all mankind) (Gadzhiev, 2008).

Dialectical interrelation between culture and education, ability of the latter to have a significant impact on the spiritual atmosphere in the society make the development of theoretical and methodological foundations of its reformation particularly important today. At the same time the task to introduce to the public consciousness a proper understanding of a true role of education, which is not only crucial for economic prosperity but also serves the basis for spiritual security, is brought into focus (Khokhrina, 2004).

A.D. Ursul gave the most detailed definition of civilizational nature and strategic importance of society's informatization process for human development. In his monograph "The path to noosphere. The strategy of survival and safe development of mankind" (Ursul, 2009a) he proved that informatization of society will be a dominant feature of civilization development not only at the stage of building the global information society, it will also be of strategic importance in the future when the information society will be changed by a different society the type of which is still difficult to predict. Most likely it could be a society with such key issues as ecology, biosphere preservation, and harmonization of a human's relations to nature.

Some ideas of the necessity to "teach the future" were also expressed by the classicists of educational thought. Thus, L.S. Vygotsky believed that "education should run ahead of the development, speed it up and cause neoplasms" (Formirovanie.., 1982).

An important characteristic of the information value in the system of university education can be obtained by considering its efficiency which in its essence represents the ratio of the information value and its quantity (Korogodin, 1990). The approach of determining information effectiveness, which allows taking into account a dynamic nature of such processes, is considered to be the most appropriate in the analysis of information processes in educational systems. In this case the information effectiveness 
reflects the increase in the information value at increasing of its quantity per unit. This approach takes into account the fact that at different current values of the information amount the growth value is not the same.

Informatization of the society has resulted in a range of fundamentally new challenges the human race never faced in the course of its history. The study of these issues began only in the last decade of the XX century. However, the results already available in this field give grounds to state a new and quite multidimensional phenomenon of the society development which will definitely have very significant implications.

The nature of these issues can be briefly described as follows. Nowadays many vital interests of a person, society, state, and the entire world civilization are largely determined by the state of the information sphere they exist in. Therefore, purposeful or unintended effects on the information sector from external or internal sources can cause serious damage to these interests and, therefore, be a threat to the information security of a person, society, and state.

Modern level of the society development is characterized by strengthening of many links in it. As for the educational system, in the information society it becomes a manufacturer of means of production, a human intelligence producer. For this reason the elements inherent in the economic institute are introduced to it. Currently, it might be said that a man simultaneously exists in different educational spaces, some of which are interrelated and inter-supplemental, but others are poorly linked or autonomous to a large extent. Besides, it is possible to distinguish personal educational spaces of some common space. Moreover, this common space can be "split" into other components when applying different classification criteria of subspaces such as subspaces of libraries, preschool institutions, higher qualification specialists' training, educational films, for example. These subspaces do not just indicate a set of elements peculiar for them but diverge these sets, make them bulky, focus on their place in real educational process. B.S. Gershunskii reasonably mentions: "Global education crisis, which is much spoken and written about in recent years and has various manifestations in all countries of the world, is due not only to the lack of education efficiency regarding its pragmatically considered economic impact... The inward nature of global education is in modern education's helplessness and inefficiency in the face of global problems of civilization" (Gershunskii, 1998). He is echoed by K.K. Kolin, emphasizing that the content of modern education system is not for an individual's preparation to life in modern information society, that "the education system is not focused on the formation of an individual's and society's new information and electronic culture which is adequate to new information reality, currently surrounding each person, changing his way of life, many values, regular patterns of behavior" (Kolin, 2010b). Besides, educational space is formed not only by the education system but factors external to it. There are, for example, specific differences in education systems and educational spaces of different states, peoples determined by their cultural and historical traditions.

The predominant approach to the interpretation of the "space" concept in Russian pedagogy lies in understanding it as a place, point, and at the same time a process through which some form of contact between a person and the environment takes place. In most pedagogical research works space is defined as an integral part of the environment which differs from the latter as it is a place of interaction between a human and the environment. The process of informatization and computerization of society favours the formation of information 
educational subspace. The computer with its rich operating system serves the cause of a dialogue of different cultures. This dialogue should not turn into a monologue. Unreasonable and unregulated dialogue can have not only positive but also negative consequences. It is worth while mentioning a current tendency which is in the process of crystallization, stiffening the frame of the educational space caused by the intensification of use of distant forms of providing information (educational television, telecommunication networks, etc.) for educational needs.

In modern world it is possible to raise the question of an informational aspect of evolution while analyzing the information model of education as one of the evolutionary processes in the society. Education as a social phenomenon, integrating education, upbringing and development, originates from an earlier biological stage at which such a fundamental characteristic feature as education was common to all animals (and, probably, to all living things) (Grinchenko 2004). In any case it is an informational aspect which is the most significant for both "competenceand-knowledge" and "globally evolutionary" vision of education. A human's formation in the education process in both approaches can be shaped by the process of the information movement and accumulation. Thus, it is meant to be a kind of an evolutionary information process. As a consequence informatization must become an important element of state policy in the field of education, especially for Russia, since modernization of Russia as manifestation of a new great innovation cycle is impossible without informatization of culture and processes and structures associated with it.

Modern education faces the following acute problems:

- compliance of spiritual and intellectual, humanitarian and natural scientific, reproductive and developing education;
- structure and scope of academic subjects content in the aspect of training effectiveness and safety;

- systemic (meta-systemic) interrelation of academic subjects;

- compliance of fundamental and universal in teaching.

It is impossible to solve these problems without the development of an information component in the educational process.

Adaptation in contemporary social and information environment is determined by the necessity of a subject of education' spiritual development. This implies not only his / her knowledge, competence and intelligence but also the culture of activity, relations, ethics, modern worldview, compliance with social-and-legal and moral norms, and careful attitude to moral values.

One of the main causes of inert transition to the information education based on innovations, use of new information technologies, modern achievements ofeconomy, scienceand pedagogical thought is a pedagogical conservatism based on old traditional methods of teaching. There also arise problems with a number of academic subjects, their content and scope in the curricular. Thus, for example, the problem of optimal combination of traditional conservative and innovative approaches in education manifests itself in disbalance in the curricular, designed in compliance with new educational standards (Lazarev, 2008; Melik-Gaikazian, 1997; Osipov, 2003).

It should benoted that theinformationalnature of the education system creates preconditions for universalization of tools and resources for interdisciplinary links. Differentiation in modern education leads to integration of many academic disciplines through the implementation of interconnections. Global educational environment favours integration of various humanitarian and 
natural-science subjects. This involves finding sources of inter-subject links and means of their implementation via unique techniques (Bezukladnikova, Mashanov, 2002; Grinchenko, 2004; Kulikovskaia, 2007; Vodop'ianov, 2003). The purpose of this process is in the formation of system of scientific thinking, ecological and information culture, creative activity and high morality as these are the features necessary for successful adaptation, life and work in the global information society.

A specific feature of any development, including education, is the emergence of the new that can occur along with the old, already existing, i.e. together with the old and under the circumstances of its change or even disappearance. Emergence of the new in evolutionary processes is already obvious at the stage of the development phenomenon research, even without penetration into its essence. The interpretations are already available, in particular, at applying the information approach stating that the elements integration results in the increment of new information in the existing system and creates the effect of a new integrity (Kolin, 2010b).

However, it should be noted that consumer characteristics of education, traditional for Western society, was changed with the evolution of the consumption itself. Thus, at pre-industrial and industrial stages of development consumption had largely an economic nature, that was obvious through a set of goods and services purchased by the consumers, and was a phase in the production process associated with its product destruction. Later the consumption enters a stage of consumerism based on the ethics of waste with its focus on the present and credit (Nalivaiko, 2008).

Understanding the relationship between the information environment of the society and the possibilities of achieving goals and interests of an individual, state and society has taken place quite recently, in the course of the last decade. It is vital to realize that information crime, information aggression, and information war are futurologists' metaphors no more. They are scientific terms denoting very specific new phenomena in our society we have to deal with, no matter we like it or not.

New trends in information technologies also bring new opportunities for the development of information crime that can be directed against individuals, society and the state. This includes the so-called computer crimes aimed mainly at obtaining unauthorized access to the databases of automated information systems of state authorities, financial institutions and industrial corporations. In the process of society informatization these systems accumulate a large amount of confidential information not only about the activities of corresponding organizations but also personal data about the citizens, their addresses, phones, property, income, etc. This information is definitely of a considerable interest to criminal gangs, many of which are already resorting to the services of the specialists in the field of information technologies.

This conference defined the creation of a global information society as one of the most important international initiatives that should be undertaken in the shortest possible time to obtain advantages for civilization development. Its distinctive feature is in the fact that major activities are grouped according to the principle of achieving specific results for certain groups of consumers. As a result, six key sub-programmes were suggested.

Thus, modern policy in education implies certain peculiarities which are due to the necessity of integration into global educational space via modern information technologies, on the one hand, and the importance of maintaining social and cultural identity, on the other hand. 


\section{References}

1. Ardov V.A. Ustoichivoe razvitie - obsuzhdenie temy [Sustainable development - problem discussion]. Global'naia bezopasnost' i ustoichivoe razvitie geotsivilizatsii: Materialy Mezhdunarodnoi nauchnoi konferentsii . St.-Petersburg, 18-19 noiabria 2011 (Global security and sustainable development of geocivilizations: Proceedings of the international scientific conference. St. Petersburg, November 18-19, 2011). Saint-Petersburg: Baltic State Technical University, 2012.

2. Bezukladnikova I. P., Mashanov A.A. Antropologiia. Paradoksy evoliutsii cheloveka [Anthropology. Paradoxes of human evolution]. Krasnoyarsk: Publishing House of Krasnoyarsk State Technical University, 2002.

3. Chumakov A.N. Sovremennyi mir i rossiiskie al'ternativy [Modern world and Russian alternatives]. Global'naia bezopasnost' $i$ ustoichivoe razvitie geotsivilizatsii: Materialy Mezhdunarodnoi nauchnoi konferentsii. St.-Petersburg, 18-19 noiabria 2011 (Global security and sustainable development of geocivilizations: Proceedings of the international scientific conference. St. Petersburg, November 18-19, 2011). Saint-Petersburg: Baltic State Technical University, 2012.

4. Gabinskaia A.A. Gumanitarnyi smysl obrazovaniia [Humanitarian meaning of education]. Dialog pokolenii i kul'tur v kontekste globalizatsii: Materialy Vezhdunarodnoi konferentsii "Konflikt pokolenii v kontekste informatizatsionnoi globalizatsii" (Dialogue of generations and cultures in the context of globalization: Proceedings of the international conference "Conflict of generations in the context of information globalization”). St.-Petersburg: Publishing House of Polytechnic. University, 2007.

5. Gadzhiev K.S. (2008). Zametki o metamorfozakh liberal'nykh tsennostei [Notes on metamorphoses of liberal values]. Voprosy filosofii, (5), 26.

6. Hegel G.W.F. Raboty raznykh let $v$ dvukh tomakh [Works of different years in two volumes]. Vol. 2. Moscow, 1971.

7. Gershunskii B.S. Filosofiia obrazovaniia dlia XXI veka [Philosophy of education for the XXI century]. Moscow, 1998.

8. Grinchenko S.N. Sistemnaia pamiat' zhivogo (kak osnova ego metaevoliutsii i periodicheskoi struktury) [Systemic memory of the living (as the basis of its meta-evolution and periodic structures). Moscow, 2004.

9. Dugin A.G. (2012). Vossleduiut i nam v ucheniiakh uspekhi [We'll also make progress in teaching]. Odnako, March 15, 15-19.

10. Formirovanie uchebnoi deiatel'nosti studentov [Formation of students' educational activity] / Ed. by V.J. Liaudi. Moscow, 1982.

11. Iatsenko M.P. (2009). Istoricheskie aspekty globalizatsii kak upravliaemogo protsessa [Historical aspects of globalization as a controlled process]. IZVESTIIA: Herzen University Journal of Humanities and Sciences, (110), 102.

12. Il'inskiy I.M. Obrazovatel'naia revoliutsiia [Educational revolution]. Moscow, 2002. Pp. 225278.

13. Ivanitskii A.M. (2004). Estestvennye nauki i problemy soznaniia [Natural sciences and the problems of consciousness]. Vestnik RAN, 1 (8), 720.

14. Khokhrina Z.V. (2004). K voprosu stanovleniia obraza konkurentosposobnoi lichnosti [On the formation of the image of a competitive personality]. Teoriia i istoriia, (3), 99-100. 
15. Kolin K.K. (2010a). Informatsionnaia kul'tura i kachestvo zhizni $\mathrm{v}$ informatsionnom obshchestve [Information culture and quality of life in the information society]. Otkrytoe obrazovanie, (6).

16. Kolin K.K. (2010b). Filosofiia informatsii i fundamental'nye problemy sovremennoi informatiki [Philosophy of information and fundamental problems of modern Informatics]. Information resources of Russia, (1), 25-28.

17. Korogodin V.I. Informatsiia i fenomen zhizni [Information and the phenomenon of life]. Pushchino, AN SSSR, 1990.

18. Korol'kov A.A. Dukhovnyi smysl russkoi kul'tury [Spiritual meaning of Russian culture]. St. Petersburg, Publishing house "RGPU named after A.I. Herzen", 2006.

19. Kotliarova I.O. Pedagogicheskaia innovatika [Pedagogical Innovatics]. Cheliabinsk: South Ural State University, 2003. 78 p.

20. Kulikovskaia A.V. Didaktika kreativnogo avtopoezisa cheloveka i ego znaniia [ Didactics of a human's creative autopoesis and his knowledge]. In: Chto takoe post-neklassicheskoe znanie [What is post-non-classical knowledge]. Moscow, Alexandrov, 2007.

21. Kulipanova N.V., Nalivaiko N.V., Orlov N.P., Ushakov E.V. (2012). Mnogoobrazie sovremennykh sotsial'nykh system i strategii globaliziruiushchegosia obrazovaniia [Diversity of modern social systems and strategies of globalizing education]. Filosofiia obrazovaniia, 6 (45), 65.

22. Kushelev V.A. Problema globalizatsii istorii [The problem of history globalization]. Dialog pokolenii i kul'tur v kontekste globalizatsii: Materialy Vezhdunarodnoi konferentsii "Konflikt pokolenii $v$ kontekste informatizatsionnoi globalizatsii" (Dialogue of generations and cultures in the context of globalization: Proceedings of the international conference "Conflict of generations in the context of information globalization"). St.-Petersburg: Publishing House of Polytechnic. University, 2007. Pp. 401-407.

23. Lazarev V.S. Upravlenie innovatsiiami v shkole [Innovation management at school]. Moscow, Center of pedagogical education, 2008. 352 p.

24. Melik-Gaikazian I.V. Informatsionnye protsessy i real'nost' [Information processes and reality]. M., Nauka, 1997.

25. Nalivaiko N.V. Filosofiia obrazovaniia: formirovanie kontseptsii [Philosophy of education: conception formation]. Novosibirsk, 2008. (Vol. XXIX. Supplement to "Philosophy of education" journal).

26. Osipov Iu.M. Osnovy innovatsionnogo menedzhmenta [The basics of innovation management]. Tomsk, Publishing house of Tomsk State University of Control Systems and Radioelectronics, 2003. $170 \mathrm{p}$.

27. Ponomareva G.M. Obrazovanie i problemy natsional'no-kul'turnoi identichnosti [Education and problems of national and cultural identity]. Lomonosovskie chteniia 2007: Osnovnye napravleniia realizatsii natsional'nykh proektov $R F v$ sisteme povysheniia kvalifikatsii prepodavatelei: $V$ 2-kh chastiakh. Chast' 1 (Lomonosov readings 2007: Key trends in implementation of national projects of the Russian Federation into the system of improvement of teachers' professional skills: in 2 vol. Vol. 1). Moscow: TEIS, 2008. Pp. 11-12.

28. Prigozhin A.I. Novovvedeniia: stimuly i prepiatstviia (sotsial'nye problem innivatiki) [Innovations: incentives and barriers (social problems of innovation). Moscow, 1989. 
29. Rakitov A.I. Filosofiia kompiuternoi revoliutsii [Philosophy of the computer revolution]. Moscow: Politizdat, 1991.

30. Rybakov N.S. Filosofiia obrazovaniia [Philosophy of education]. Globalistika. Entsiklopediia (Global studies. Encyclopedia). Moscow, 2003. P. 1100.

31. Stepin V.S. Filosofiia nauki. Obshchie problemy [Philosophy of science. Mutual problems]. Moscow, Gardariki, 2006. 384 p.

32. Toffler A., Toffler Kh. Revoliutsionnoe bogatstvo [Revolutionary wealth]. Moscow, 2007.

33. Ursul A.D. The path to noosphere. The strategy of survival and safe development of mankind. Moscow, 2009a.

34. Ursul A.D. (2009b). Obrazovatel'naia revoliutsiia v perspective ustoichivogo budushchego [Educational revolution in the perspective of sustainable future]. // Knowledge. Understanding. Skill, (1), (2), (3).

35. Ursul A.D., Ursul T.A. (2012). Universal'nyi (global'nyi) evoliutsionism i global'nye issledovaniia [Universal (global) evolutionism and global studies]. NB: Philosophy researches, (1).

36. Vodop'ianov P.A. Noosfera [Noosphere]. In: Noveishii filosofskii slovar' [Newest philosophical dictionary]. 3 rd ed. Minsk, 2003. P. 703.

\section{Коммуникационный потенциал информационных технологий \\ в глобальном образовательном пространстве}

C.В. Бурмага

Сибирский федеральный университет Россия, 660041, Красноярск, пр. Свободныий, 79

В статье анализируются новые коммуникационные возможности, возникающие в образовательной системе при использовании современных информационных технологий. Проведя сочиально-философский анализ, автор доказывает, что наряду с явными преимуществами возникают проблемы, многие из которых носят характер отчуждения. В частности нарушаются не только традиционные субъект-объектные связи в вузе, но и формируются новые дистанционные отношения в молодежной среде.

Особенности взаимодействия информации и образовательной сферы во многом определяют потенциальные направления развития всех социальных институтов. Социальнофилософский анализ в этом плане приобретает особую актуальность, поскольку философия информачии в России интенсивно развивается и играет все большую роль в науке благодаря развертыванию прочесса становления глобального информаџионного общества. Одним из следствий ускоренного реформирования образовательной сферы в направлении внедрения информачионных технологий являются отчуждения в молодежной вообще и в студенческой среде в частности.

Современный уровень развития общества характеризуется усилением многих связей в нем. В том числе система образования становится в информационном обществе производителем средств производства, производителем человеческого интеллекта и по этой причине у него появляются элементы, присущие экономическому институту. В настоящее время можно говорить о том, что человек существует одновременно в различных образовательных 
пространствах, некоторые из них взаимосвязаны и взаимодополнительны, но другие слабо связаны между собой или же практически автономны.

Проиесс информатизации и компьютеризаџии общества способствует формированию своего информачионного образовательного подпространства. Компьютер со своей богатой операционной средой служит диалогу различных культур.

Формирование человека в прочессе образования может моделироваться процессом движения и накопления информации, т.е. мыслиться как своего рода эволюиионный информационный прочесс. Вследствие этого информатизачия должна стать важнейшим элементом государственной политики в области образования, особенно для России, ибо модернизаиия России как проявление нового большого инновационного цикла без информатизации культуры и сопряженных с ней процессов и структур просто невозможна.

Адаптация в современной сочиально-информационной среде обусловлена необходимостью развития духовного начала у субъекта обучения, что предполагает не только наличие знаний, компетентности и интеллекта субъекта, но и культуры деятельности, культуры отношений, этики, современного мировоззрения, соблюдение им соииально-правовых норм и норм морали, бережное отношение к нравственным иенностям.

Одной из основных причин инертности перехода $к$ информаџионному образованию, основанному на инновациях, использовании новых информаџионных технологий, на современныхдостиженияхэкономики, наукиипедагогическоймысли,являетсяпедагогический консерватизм, опирающийся на традиционные методы обучения. Дифференциация в современном образовании предполагает наличие интеграции множества учебных дисциплин на основе реализации межсистемных связей. Через общую образовательную среду различные гуманитарные и естественно-научные предметы интегрируются, что заставляет находить источники межпредметных связей и средства их реализации, предлагая авторские методики. Целью этого прочесса является формирование у учащихся системного научного мышления, экологической и информационной культуры, творческой активности и высокой нравственности - качеств, которые позволят им успешно адаптироваться, жить и работать в глобальном информачионном обществе.

Ключевые слова: коммуникационный потенциал, информационные технологии, образовательное пространство, отчуждение, глобальное информационное общество, информационный ресурс.

Научная специиальность: 09.00.00 - философские науки. 